\title{
DEPRESSION IN PATIENTS WITH PARKINSON'S DISEASE WITH DEMENTIA
}

\author{
Perovic Zlatana, ${ }^{1}$ Cukic Mirjana ${ }^{2}$ \\ ${ }^{1}$ Neurology department, General Hospital Niksic, Montenegro \\ ${ }^{2}$ Department of Neurology, University Clinical Center of Montenegro, Podgorica, Montenegro
}

Primljen/Received 10. 02. 2017. god.

Abstract: Introduction: Parkinson's disease is a multisystem disorder which is characterized by a combination of motor and non-motor symptoms. Non-motor symptoms include: depression, cognitive impairment, autonomic and sensor symptoms. It is difficult to detect and treat depression symptoms in patients with Parkinson's disease with dementia. Early identification and treatment of depression symptoms can greatly improve the quality of life in these patients, as well as facilitate the quality of caregivers' lives.

Goal of the paper: The aim of our research was to evaluate frequency of depression occurrence in patients with Parkinson's disease with cognitive impairment.

Patients and methods: We did a prospective study which included 59 PD patients, who came for a regular check-up to Neurological infirmary of the General Hospital in Niksic, in the interval from $1^{\text {st }}$ January 2016to $31^{\text {st }}$ December 2016, all of whom were previously diagnosed with Parkinson's disease. We tested their cognitive status using the Mini Mental State Examination scale. Out of 59 patients, 32 displayed cognitive deficit and were included in further research. We gave directions about testing to guardians or caregivers of the patients who displayed moderate or distinct cognitive impairment. The testing was done on the next check-up, with Cornell's depression scale.

Results: Research showed that out of 32 patients, 5 (15.6\%) didn't suffer from depression, $8(25 \%)$ probably suffered from major depression, while 19 (59.4\%) definitely suffered from major depression. On the cognitive scale, $6(18.8 \%)$ patients had mild, 11 (34.4\%) moderate and 15 (46.9\%) distinct cognitive deficit. Out of 8 patients with probable depression $3(9.4 \%)$ had mild, 3 (9.4\%) had moderate and $2(6.2 \%)$ distinct cognitive deficit. We can also: conclude that out of $19(59.4 \%)$ with certain depression, $1(3.1 \%)$ had mild, $5(15.6 \%)$ had medium severe, and $13(40.6 \%)$ had severe cognitive deficit.
Prihvaćen/Accepted 24. 03. 2017. god.

Conclusion: Prevalence of depression and dementia in Parkinson's diseasepatients is high. Our patients have moderate cognitive deficit in $34.4 \%$ of the cases, and distinct cognitive deficit in $46.9 \%$ of the cases; while $59.4 \%$ definitely suffers from major depression at some point of their illness. Their early detection is of great importance for treatment and quality of life of these patients.

Keywords: depression, dementia, Parkinson disease.

\section{INTRODUCTION}

Parkinson's disease (PD) is a multisystem degenerative disorder which is characterized by a combination of motor and non-motor symptoms $(1,2)$. Nonmotor symptoms include: depression, cognitive impairment, autonomic and sensor symptoms $(2,3)$. It can be very complicated to identify depression in PD patients who have cognitive impairment, for known depression scales are not reliable markers to evaluate depression (4). Dementia is present in more than $30 \%$ of PD patients, especially in those over 70 years old $(5,6)$. Depression and dementia are often connected comorbidities; however, depression can be considered a risk factor for dementia development in PD (7). Early depression identification and treatment can significantly improve the quality of life in PD patients, as well as facilitate the quality of caregivers' lives (7-10). Depression may appear as one of the first symptoms of PD, but it can appear many years before the beginning of motor symptoms of the illness. Dementia in PD implies impairment of executive function, attention, slow cognitive speed, recalling learned information, and visuospatial problem (11). Dementia is also a part of neurodegenerative illnesses, including PD (12-14). Prevalence of major depression in PD patients is from $2.7 \%$ to $8.2 \%$ and from $13 \%$ to $34.5 \%$ in case of minor de- 
pression (14-16). Prevalence of mild cognitive impairment in PD patients is from $18.9 \%$ to 55\% (17-19). PD patients with distinct cognitive deficit, who need a caregiver, form a special group. Mild cognitive deficit is present in about $35 \%$ of the patients at the beginning of motor symptoms and in about $50 \%$ of the patients after 5 years of being ill (20).

Depression is a very common in dementia as part of PD. Therefore, its early identification is of the essence in order to begin early medicament therapy, which will in the long-run improve the quality of life both of the patient and the caregiver $(11,16,21)$.

\section{PATIENTS AND METHODS}

We researched presence and degree of depression in patients with Parkinson's disease with cognitive impairment.

Patients that were tested are those who came for a regular check-up to Neurological infirmary of the General Hospital in Niksic, Montenegro, in the interval from $1^{\text {st }}$ January to $31^{\text {st }}$ December 2016, all previously diagnosed with idiopathic Parkinson's disease.

We tested cognitive status in 59 patients with idiopathic Parkinson's disease, using the MMSE scale. Out of the 59 patients, 32 were included in the research, all of whom tested less than 23 points on the Mini Mental State Examination (MMSE). They were divided to three groups: with mild (20-23), moderate (11-19), and severe cognitive deficit ( $0-10$ points). After the applied MMSE testing, patients or caregivers of the patients received instructions about observing the patient in the next 7 days, when the testing with the Cornell's scale for depression would be applied (13). Cornell's scale for depression was applied on patients with dementia in order to achieve a more objective assessment. The scale consists of 19 parameters which are grouped into 5 groups: mood-related signs, behavioral disturbances, physical signs, cyclic functions and ideational disturbances. Each item is rated on a scale of 0-2 (0- absent, 1 - mild or intermittent, 2- severe). Score above 10 indicates probable major depression; score above 18 indicates definite major depression; score below 6 as a rule is associated with absence of significant depressive symptoms (22).

Scores are presented tabularly and in percentage. We used the Chi-square test to connect depression and cognitive impairment.

We researched the significance of the Cornell scale in detecting depression in PD patients.

Ethics Statement: The paper was approved by the Ethical committee of the hospital where we did the research, and all the patients signed the informational consent before the beginning of research.

\section{RESULTS}

Out of 32 patients with cognitive deficit, 17 $(53.1 \%)$ were men and $15(46.9 \%)$ were women (Table 1), average age of 73.03 years old (Table 2), average illness duration being 8.175 years (Table 3). Out of 32 patients included in the study, 5 (15.6\%) didn't suffer from depression, 8 (25\%) probably suffered from depression, while 19 (59.4\%) definitely suffered from major depression. On the MMSE scale, $6(18.8 \%)$ patients had mild, 11 (34.4\%) moderate and 15 (46.9\%) distinct cognitive deficit (Table 3).

Table 1. Distribution of patients with PD and cognitive impairment in relation to gender

\begin{tabular}{|c|c|c|c|c|c|}
\hline \multicolumn{2}{|c|}{} & Frequency & Percent & $\begin{array}{c}\text { Valid } \\
\text { Percent }\end{array}$ & $\begin{array}{c}\text { Cumulative } \\
\text { Percent }\end{array}$ \\
\hline \multirow{3}{*}{ Valid } & Male & 17 & 53.1 & 53.1 & 53.1 \\
\cline { 2 - 6 } & Female & 15 & 46.9 & 46.9 & 100.0 \\
\cline { 2 - 6 } & Total & 32 & 100.0 & 100.0 & \\
\hline
\end{tabular}

Table 2. Average agepatients with PD and cognitive impairment

The mean age was 73.03 years

\begin{tabular}{|c|c|c|}
\hline \multicolumn{3}{|c|}{ Statistics } \\
\hline \multicolumn{3}{|c|}{ Age } \\
\hline \multirow{3}{*}{$\mathrm{N}$} & Valid & 32 \\
\cline { 2 - 4 } & Missing & 0 \\
\hline \multicolumn{3}{|c|}{ Mean } \\
\hline
\end{tabular}

Table 3. The average length of the disease

\begin{tabular}{|c|c|c|}
\hline \multicolumn{3}{|c|}{ Statistics } \\
\hline \multicolumn{3}{|c|}{ Duration of illness } \\
\hline \multirow{3}{*}{$\mathrm{N}$} & Valid & 32 \\
\cline { 2 - 3 } & Missing & 0 \\
\hline \multicolumn{2}{|c|}{ Mean } & 8.175 \\
\hline
\end{tabular}

Out of 8 patients with probable depression 3 (9.4\%) had mild, $3(9.4 \%)$ had moderate and $2(6.2 \%)$ distinct cognitive deficit. We can also conclude that out of $19(59.4 \%)$ with certain depression, $1(3.1 \%)$ had mild, $5(15.6 \%)$ had moderate, and $13(40.6 \%)$ had severe cognitive deficit (Table 4). There is a significant correlation between depression and cognitive impairment (Table 5). The size of the impact of depression on cognitive impairment is a high (Table 6).

We feel that the Cornell Scale is greatly significant in identifying depression in these patients (Table 7). 
Table 4. The incidence of depression compared to the weight of dementia:

Analysis of the data by $\chi^{2}$ - test we got the results:cognitive impairment

\begin{tabular}{|c|c|c|c|c|c|c|}
\hline \multicolumn{7}{|c|}{ Depression * Cognitive impairmentCrosstabulation } \\
\hline & & & \multicolumn{3}{|c|}{ Cognitive impairment } & \multirow{2}{*}{ Total } \\
\hline & & & mild & medium & severe & \\
\hline \multirow{12}{*}{ Depression } & \multirow{4}{*}{ no } & Count & 2 & 3 & 0 & 5 \\
\hline & & $\%$ within depression & $40.0 \%$ & $60.0 \%$ & $0.0 \%$ & $100.0 \%$ \\
\hline & & $\%$ within cognitive impairment & $33.3 \%$ & $27.3 \%$ & $0.0 \%$ & $15.6 \%$ \\
\hline & & $\%$ of Total & $6.2 \%$ & $9.4 \%$ & $0.0 \%$ & $15.6 \%$ \\
\hline & \multirow{4}{*}{ probably } & Count & 3 & 3 & 2 & 8 \\
\hline & & $\%$ within depression & $37.5 \%$ & $37.5 \%$ & $25.0 \%$ & $100.0 \%$ \\
\hline & & $\%$ within cognitive impairment & $50.0 \%$ & $27.3 \%$ & $13.3 \%$ & $25.0 \%$ \\
\hline & & $\%$ of Total & $9.4 \%$ & $9.4 \%$ & $6.2 \%$ & $25.0 \%$ \\
\hline & \multirow{4}{*}{ certainly } & Count & 1 & 5 & 13 & 19 \\
\hline & & $\%$ within depression & $5.3 \%$ & $26.3 \%$ & $68.4 \%$ & $100.0 \%$ \\
\hline & & $\%$ within Cognitive impairment & $16.7 \%$ & $45.5 \%$ & $86.7 \%$ & $59.4 \%$ \\
\hline & & $\%$ of Total & $3.1 \%$ & $15.6 \%$ & $40.6 \%$ & $59.4 \%$ \\
\hline \multirow{4}{*}{\multicolumn{2}{|c|}{ Total }} & Count & 6 & 11 & 15 & 32 \\
\hline & & $\%$ within depression & $18.8 \%$ & $34.4 \%$ & $46.9 \%$ & $100.0 \%$ \\
\hline & & $\%$ within Cognitive impairment & $100.0 \%$ & $100.0 \%$ & $100.0 \%$ & $100.0 \%$ \\
\hline & & $\%$ of Total & $18.8 \%$ & $34.4 \%$ & $46.9 \%$ & $100.0 \%$ \\
\hline
\end{tabular}

Cornel scale: score $>10$ probable depression, score $>18$ certainly depression MMSE scale cognitive impairment: (20-23) mild, (11-19) medium, (0-10)severe

Table 5. The correlation between depression and cognitive impairment

\begin{tabular}{|l|c|c|c|}
\hline \multicolumn{4}{|c|}{ Chi-Square Tests } \\
\hline & Value & df & $\begin{array}{c}\text { Asymp. Sig. } \\
\text { (2-sided) }\end{array}$ \\
\hline Pearson Chi-Square & $10.926^{\mathrm{a}}$ & 4 & .027 \\
\hline Likelihood Ratio & 13.160 & 4 & .011 \\
\hline Linear-by-Linear Association & 9.508 & 1 & .002 \\
\hline N of Valid Cases & 32 & & \\
\hline \multicolumn{4}{|c|}{ a. 7 cells (77.8\%) have expected count less than 5. } \\
The minimum expected count is .94. \\
\hline
\end{tabular}

Sig. 0027, indicating that significant correlation Yeats
Table 6. The size of the impact of depression on cognitive impairment

\begin{tabular}{|l|c|c|c|}
\hline \multicolumn{4}{|c|}{ Symmetric Measures } \\
\hline \multicolumn{2}{|c|}{} & Value & $\begin{array}{c}\text { Approx. } \\
\text { Sig. }\end{array}$ \\
\hline \multirow{2}{*}{ Nominal by Nominal } & Phi & .584 & .027 \\
\cline { 2 - 4 } & Cramer's V & .413 & .027 \\
\hline N of Valid Cases & 32 & \\
\hline a. Not assuming the null hypothesis. \\
\hline $\begin{array}{l}\text { b. Using the asymptotic standard error assuming the null } \\
\text { hypothesis. }\end{array}$ \\
\hline
\end{tabular}

The size of the impact of the 0,413 high.

Table 7. Cornel scale in detecting depression

\begin{tabular}{|l|c|c|c|c|c|c|}
\hline \multicolumn{1}{|c|}{ Tests of Normality } \\
\hline & \multicolumn{3}{|c|}{ Kolmogorov-Smirnov $^{\text {a }}$} & \multicolumn{3}{c|}{ Shapiro-Wilk } \\
\cline { 2 - 8 } & Statistic & $\mathrm{df}$ & Sig. & Statistic & df & Sig. \\
\hline Cornel scale & .100 & 32 & $.200^{*}$ & .983 & 32 & .884 \\
\hline Depression & .364 & 32 & .000 & .707 & 32 & .000 \\
\hline$*$ This is a lower bound of the true significance. \\
\hline \\
a. Lilliefors Significance Correction
\end{tabular}




\section{DISCUSSION}

Patients with Parkinson's disease, in over $50 \%$ of the cases, suffer from significant cognitive impairment at a certain stage of the illness, which is in accordance with many previous studies (17-20). In case of our PD patients, with cognitive impairment, at a certain point of the illness, $25 \%$ probably suffer from major depression, and $59.4 \%$ definitely suffer from depression, which is more than in previously shown results in other studies (14-16).

Cornell's scale may help us in our daily work to early diagnose depression in PD patients with dementia, which is a prerequisite for early treatment of depression of these patients (22).

Minimizing the disability includes treating not just motor symptoms, but treating also dementia, depression and psychosis. Therefore, identification of clinically relevant screening and diagnostic tools for depression and cognitive impairment are necessary in PD patients (22-23).

\section{CONCLUSION}

Depression and dementia are a common problem in PD patients. Their detection is highly significant to clinical practice. PD patients with cognitive impairment present a special difficulty in identifying depression.
Abbreviations
MMSE - Mini Mental State Examination
PD - Parkinson's disease

\section{CONFLICT OF INTEREST}

The authors declare that there is no conflict of interest.

\section{Licensing}

This work is licensed under a Creative Commons Attribution 4.0 International (CC BY 4.0)

\title{
Sažetak
}

\section{DEPRESIJA KOD PACIJENATA SA PARKINSONOVOM BOLEŠĆU SA DEMENCIJOM}

\author{
Perovic Zlatana, ${ }^{1}$ Cukic Mirjana ${ }^{2}$ \\ ${ }^{1}$ Neurology department, General Hospital Niksic, Montenegro \\ ${ }^{2}$ Department of Neurology, University Clinical Center of Montenegro, Podgorica, Montenegro
}

Uvod: Parkinsonova bolest je multisistemski poremećaj koji se karakteriše kombinacijom motornih i nemotornih simptoma. Nemotorni simptomi su depresija, kognitivno oštećenje, autonomni i senzorni simptomi. Otkrivanje i lečenje depresije je otežavajuće kod pacijenata sa Parkinsonovom bolešću i demencijom. Rano prepoznavanje i lečenje simptoma depresije može značajno poboljšati kvalitet života ovih pacijenata, ali i olakšati kvalitet života i negovatelja.

Cilj rada: Cilj našeg istraživanja bio je da se proceni učestalost depresije kod pacijenata sa Parkinsonovom bolešću sa kognitivnim oštećenjem.

Metod rada: Sproveli smo prospektivnu studiju koja je uključila 59 pacijenata sa PB koji su se javili na redovni pregled u Neurološku ambulantu Opšte bolnice Nikšić u Crnoj Gori, u periodu od 01. 01. 2016. do 31. 12. 2016. g, kod kojih je ranije postavljena dijagnoza Parkinsonove bolesti. Kognitivni status pacijenata smo testirali pomoću Minimental skale. Od ukupno 59 pacijenata, 32 su na ovoj skali pokazali kognitivni deficit i uključeni su u dalje istaživanje. Kod pacijanata koji su pokazali umereno ili izraženo kognitivno oštećenje dali smo uputstva o testiranju starateljima ili nego- vateljima pacijenata. Na narednoj kontroli, je testiranje urađeno Korlenovom skalom za depresiju.

Rezultati: Od 32 pacijenta sa kognitivnim deficitom, $17(53,1 \%)$ su bili muškarcii $15(46,9 \%)$ žene, prosečne starosti 73,03 godina, sa prosečnom dužinom trajanja bolesti od 8,175 godina. Istraživanje je pokazalo da od 32 pacijenta $5(15,6 \%)$ nema depresiju, 8 (25\%) verovatno ima veliku depresiju, dok $19(59,4 \%)$ sigurno ima veliku depresiju. Na MMSE skali $6(18,8 \%)$ pacijenata su imali blagi, $11(34,4 \%)$ umereni i $15(46,9 \%)$ izraženi kognitivni deficit. Od 8 pacijenata sa verovatnom depresijom 3 $(9,4 \%)$ ima blagi, $3(9,4 \%)$ srednjii $2(6,2 \%)$ izraženi kognitivni deficit. Takođe se može zaključiti da od $19(59,4 \%)$ sa sigurnom depresijom $1(3,1 \%)$ ima blagi, $5(15,6 \%)$ ima srednje teškii $13(40,6 \%)$ teški kognitivni deficit.

Zaključak: Učestalost depresije i demencije kod obolelih od Parkinsonove bolesti je visoka. Naši pacijenti imaju u 34,4\% umereni i u 46,9\% izražen kognitivni deficit, dok 59,4\% ima sigurno depresiju u nekom trenutku bolesti. Njihovo rano otkrivanje je od velikog značaja za lečenje i kvalitet života ovih pacijenata.

Ključne reči: depresija, demencija, Parkinsonova bolest. 


\section{REFERENCES}

1. Lang AE, Lozano AM.Parkinson's disease.First of two parts. N Engl J Med. 1998; 339 (15): 1044-53.

2. Stacy M. Nonmotor symptoms in Parkinson's disease. Int J Neurosci. 2011; 121(2): 9-17.

3. Zweig RM, Disbrow EA, Javalkar V. Cognitive and psychiatric disturbances in Parkinsoniansyndromes. Neurologic clinics. 2016; 34(1): 235-46.

4..Torbey E, Pachana NA, Dissanavaka NN. Depression rating scales in Parkinson's disease: A critical review updating recent literature. J affect disord. 2015; 184: 216-24.

5. Aarsland D, Tandberg E, Larsen JP, Cummings JL. Frequency of dementia in Parkinson disease. Arch Neurol. 1996; 53(6): 538-42.

6. Biggins CA, Boyd JL, Harrop FM, Madeley P, Mindham RH, Randall JI et al.A controlled, longitudinal study of dementia in Parkinson's disease.J NeurolNeurosurg Psychiatry. 1992; 55(7): 566-71.

7. Rickards H. Depression in neurological disorders: an update. Curr Opin Psychiatry. 2006; 19(3): 294-8.

8. Lim SY, Fox SH, Lang AE. Overview of the extranigral aspects of Parkinson disease. Arch Neurol. 2009; 66(2): 167-72.

9. Weintraub D, Stern MB.Psychiatric complications in Parkinson disease. Am J Geriatr Psychiatry. 2005; 13(10): 844-51.

10. Schrag A. Quality of life and depression in Parkinson's disease. J Neurol Sci. 2006; 248(1-2): 151-7.

11. Baquero M, Martin N.Depressive symptoms in neurodegenerative diseases. World J Clin Cases. 2015; 3(8): 682-93.

12. Caballol N, Marti MJ, Tolosa E. Cognitive dysfunction and dementia in Parkinson disease. Mov Disord. 2007; 22 (17): 358-66.

\section{Correspondence to/Autor za korespondenciju}

Zlatana Perović MD

General Hosptal Niksic, Montenegro

Str Radoia Dakica bb, Niksic, Montenegro

Tel +38269351378

Email: zlataperovic@gmail.com
13. Hancock P, Larner AJ. Cornell Scale for Depression in Dementia: clinical utility in a memory clinic. Int J Psychiatry ClinPract. 2015; 19(1): 71-4.

14. Weintraub D, Moberg PJ, Duda JE, Katz IR, Stern MB. Recognition and treatment of depression in Parkinson's disease. J Geriatr Psychiatry Neurol. 2003; 16(3): 178-83.

15. Costa A, Peppe A, Carlesimo GA, Pasqualetti P, Caltagirone C. Alexithymia in Parkinson's disease is related to severity of depressive symptoms. Eur J Neurol. 2006; 13(8): 836-41.

16. Grover S, Somaiya M, Kumar S, Avasthi A. Psychiatric aspects of Parkinson's disease. J Neurosci Rural Pract. 2015; 6(1): 65-76.

17. Aarsland D, Kurz MW. The epidemiology of dementia associated with Parkinson disease. J Neurol Sci. 2010; 289(1-2): 18-22.

18. Caviness JN, Driver-Dunckley E, Connor DJ, Sabbagh MN, Hentz JG, Noble B, et al. Defining mild cognitive impairment in Parkinson's disease. Mov.Disord.2007; 22(9): 1272-7.

19. Muslimovic D, Post B, Speelman JD, Schmand B. Cognitive profile of patients with newly diagnosed Parkinson disease. Neurology. 2005; 65(8): 1239-45.

20. Broeders M, de Bie RM, Velseboer DC, Speelman JD, Muslimovic D, Schmand B. Evolution of mild cognitive impairment in Parkinson disease. Neurology. 2013; 81(4): 346-52.

21. Connolly B, Fox SH.Treatment of cognitive, psychiatric, and affective disorders associated with Parkinson's disease. Neurotherapeutics. 2014; 11(1): 78-91.

22. Williams JR, Marsh L. Validity of the Cornell scale for depression in dementia in Parkinson's disease with and without cognitive impairment. Movement Disorder. 2009; 24(3): 433-7.

23. Weintraub D, Moberg PJ, Duda JE, Katz IR, Stern MB. Effect of psychiatric and other nonmotor symptoms on disability in Parkinson's disease. J Am GeriatrSoc. 2004; 52(5): 784-8. 